https://doi.org/10.52449/1857-4114.2021.37-1.02

CZU: 796:341.7(478)

\title{
SPORTS DIPLOMACY OF THE REPUBLIC OF MOLDOVA: FORMS AND SPECIFICITY OF MANIFESTATION
}

\author{
Popov Anton ${ }^{1}$ \\ ${ }^{1}$ Academy of Public Administration, Chisinau, Republic of Moldova
}

\begin{abstract}
This article examines the effectiveness of high performance sports as a tool for establishing and strengthening cooperation between the Republic of Moldova and other states, by creating a positive image and forming relations that official diplomacy is not able to carry out. In this regard, the experience of using sports diplomacy in the establishment of bilateral relations, as well as the solution of interstate, interethnic conflicts in the post-Soviet space is analyzed. In particular, the role of "football diplomacy" in resuming the negotiation process between Chisinau and Tiraspol, creating conditions conducive to resolving the long-term conflict is considered. In addition, football competitions between the embassies accredited in the Republic of Moldova, as well as the participation of Moldovan diplomatic missions in similar competitions abroad, play an important role in shaping the positive image of our country in the international arena. An essential factor of "soft power" is sports dances and the success of Moldovan athletes at international venues.

Keywords: public diplomacy, sports diplomacy, "football diplomacy", "soft power", settlement of the Transnistrian conflict, social "attractor", dance sports federation, country's image.
\end{abstract}

Introduction. Simultaneously with the revival of the Olympic Movement at the end of the nineteenth century, modern sports diplomacy also originates as a derivative of the foreign policy and informal diplomatic functions of high performance sports. Given the effectiveness of international sporting events as a way to build and strengthen intergovernmental ties, governments are systematically trying to influence sport in a variety of ways, including through administrative or financial means. In almost all countries, national sports teams participating in major international competitions are subsidized by the state, the government of which receives, figuratively speaking, an indulgence to demonstrate their involvement in sports at the opening of international competitions, official celebrations of sports victories and honors of champions. The athletes themselves are most often viewed as "ambassadors" of a particular state, performing certain diplomatic missions.

In the Republic of Moldova, sports diplomacy, more often and more interestingly, manifests itself outside the sphere of budgetary influence of the Moldovan state and outside the range of Olympic sports. This phenomenon is observed not only in the Republic of Moldova, but also in other post-Soviet republics, in which sports are also financed on a leftover basis, but the need to use it as a diplomatic tool increases as the need to systematically promote a positive image of the country among other countries and, most importantly, to establish certain relations between the parties, which official diplomacy is not able to carry out.

As the practice of sports diplomacy convinces, such relations are formed during meetings of responsible individuals within the framework of various championships. Considering the fact that in the CIS countries 
everyone loves football, as well as its enormous impact on people and on the image of countries and their politicians, it is not surprising that "football diplomacy" has become, in a certain sense, an indispensable tool for settling foreign and domestic political problems. as well as interethnic relations.

In this context, we consider it necessary to make the following remark. A classic example of the participation of sport in the consolidation of society, solving complex problems of social and cultural identity is South Africa in the 1990s, after Nelson Mandela came to power and the beginning of democratic reforms. The fact is that even in sports, South Africa was divided - white athletes preferred rugby, black ones preferred football. South Africa was banned from the African Cups since 1957 due to the apartheid regime, and it was expelled from FIFA in 1976 after police shot 170 rebellious students in the city of Sueto [1].

A huge sports fan, Mandela was convinced that "Sport can change the world. Sport can inspire, sport can connect like few other things. It speaks to young people in a language they understand. Sport can create hope where there was only despair. Sport is a more powerful force for breaking down race barriers than governments. Sport laughs in the face of all kinds of discrimination" [2]. He proved the truth of these words by his direct participation in the process of their materialization.

A certain interest, in this regard, is the "football diplomacy" of the Republic of Armenia, which has shown itself especially in the qualifying cycle of the 2010 World Cup. For example, on September 6, 2008, the President of the Republic of Turkey Abdullah Gul arrived in Armenia at the invitation of its President Serzh Sargsyan. The formal reason for the visit was attending a football match between the national teams of Turkey and Armenia. In turn, the President of Armenia was invited to attend the return qualifying match, which took place in October 2009 [3].
As a result of interested discussions between the presidents and negotiations between delegations, Ankara and Yerevan began to come to the understanding that the lack of bilateral relations between these countries does not correspond to the interests of their peoples. In this regard, it should be noted that football diplomacy had a positive impact on the process of preparation and signing in Zurich of the so-called "Protocols" on the establishment of diplomatic relations between Turkey and Armenia [4]. In addition, after the first round of "football diplomacy", the "active phase" began to resolve the Karabakh conflict [3].

In this context, we note that the first meeting between Azerbaijani President Aliyev and Armenian Prime Minister Pashinyan took place in Moscow as part of the opening ceremony of the 2018 FIFA World Cup. During the meeting, the leaders discussed issues related to the prevention of border conflicts; the need to continue negotiations on a peaceful settlement of the conflict; establishment of operational communication [5].

In connection with the tragic events (in the fall of 2020) in the Turkey-ArmeniaAzerbaijan geopolitical triangle, it should be noted that "football diplomacy" cannot replace the complex of official political and diplomatic ways of resolving conflicts. It can only supplement them.

During this period, all the events related to "football diplomacy" within the CIS, especially the experience of "football matches" between the presidents of Armenia and Turkey, undoubtedly influenced the events in the Republic of Moldova in terms of the settlement of the Transnistrian conflict. On August 24, 2010, in Tiraspol, within the framework of the Sheriff - Basel football match, the first meeting of Prime Minister Vlad Filat with the leader of Transnistria Igor Smirnov took place. According to the Deputy Prime Minister for Reintegration of the Republic of Moldova, Victor Osipov, at the meeting "sports were 
discussed and only general items on the bilateral agenda were mentioned"[6]. According to the OSCE Special Representative for Protracted Conflicts Bolat Nurgaliyev, "the August meeting of Filat and Smirnov within the framework of" football diplomacy "can bear fruit" [6]. Chisinau did not object to such an assessment of the situation, and through the mouth of officials it was announced that they were ready to "continue what the press called football diplomacy" [7].

At the end of September 2010, the media from both banks of the Dniester wrote about Filat's arrival at the Europa League group stage football match between Sheriff Tiraspol and Dynamo Kyiv. According to Chișinău officials, the invitation to the match came from the Ambassador Extraordinary and Plenipotentiary of Ukraine to Moldova [8], while Tiraspol claimed that the initiative came from Igor Smirnov, who himself therefore emphasized: "Today there is a lot of talk about 'football diplomacy'. I officially invited the Prime Minister of Moldova Vlad Filat ... I am trying to resume work ... at the official level. We are ready to negotiate when certain conditions are created. The guarantor countries agree with this position "[9].

There is reason to assume that one of the elements of creating these conditions is the resumption of the movement of the ChisinauOdessa passenger train, which was supposed to follow through the cities of Bendery, Tiraspol and other settlements of Transnistria. Attending the ceremony of sending the train on this route, the Ukrainian Ambassador to the Republic of Moldova said that this train "will not only bring the two countries (Moldova and Ukraine) closer together, but also contribute to the Transnistrian settlement" [23]. This was the first result of "football diplomacy", which, judging by the publications, satisfied not only Chisinau and Tiraspol, but also the mediators in the negotiations in the "5+2" format. (The format implies the participation in the negotiations of the guarantor countries - Russia and Ukraine; the parties to the conflict Moldova and Transnistria; the mediator - the OSCE; the EU and the United States as observers of the process).

As OSCE Chairman Audronus Azubalis rightly noted, football fans were the first "diplomats" who established informal relations between the two banks of the Dniester. He puts them on a par with officials from Chisinau and Tiraspol, who are trying to establish official contacts [10]. However, the overexploitation of the capabilities of "football diplomacy" and its substitution for official negotiations reduces the quality of the results achieved and compromises its effectiveness. On July 8, 2011, during the Moldova Super Cup match between the football teams Dacia and Iskra-Stal, Smirnov and Filat met once again [11].

It is important to note that the risk of a decrease in the influence of sports diplomacy on the process of establishing and consolidating relations between the two banks of the Dniester was mainly concerned with the Tiraspol administration: "We cannot exclude the possibility that" football diplomacy "will continue. But ... the optimal mechanism for resolving issues is a professional, substantive dialogue with the participation of all those who should be involved "[12]. June 4, 2013 within the framework of the final match of the Moldova Cup, there was a kind of failure in the public diplomacy of Chisinau and Tiraspol. Before the start of the game, a military band appeared on the football field to perform the anthem of the Republic of Moldova. The fans of the visiting sector began to behave defiantly, thereby showing disrespect for the anthem ceremony. As a result, the football club "Tiraspol" was fined a record amount of \$ 16.6 thousand [13]. After this incident, the place of "football diplomacy" between Chisinau and Tiraspol practically remained in history.

We examined two aspects of football diplomacy and, in principle, sports diplomacy, manifested in Moldova: on the one hand, a meeting of officials in the framework of 
national or international football championships, and on the other hand, the direct participation of football fans in the implementation of public diplomacy to unite people from both banks of the Dniester, regardless on their nationality, beliefs and language in which they communicate. Sometimes this process is accompanied by certain incidents.

Let us briefly consider the third form of manifestation of "football diplomacy", which is more like a cultural event, but has its definite place in the process of consolidating relations between various diplomatic missions, between them and representatives of state and non-state structures in the host country. Let us note in this regard that over the past ten years, "football diplomacy", with the participation of diplomats, has shown itself more and more actively and at the same time more creatively, within the broader context of public and sports diplomacy of the post-Soviet republics.

Of interest in this regard is the initiative of Yuri Belous, President of the Football Market group of companies of the Russian Federation, to organize the first international tournament - "Unofficial World Championship among the Embassies in Russia". Representatives of the Moldovan Embassy in the Russian Federation took part among the 12 football teams of diplomatic workers - Spain, China, Kazakhstan and other countries. According to the organizers of the tournament, "Football is a universal communicative key, an instrument of friendship, cooperation, trust in each other." (The diplomats played football: the Moldovan embassy did not remain in debt) According to the Ambassador Extraordinary and Plenipotentiary to the Russian Federation, Andrei Neguța, his team took to the field to show that "Moldova also has sports" [14].

No less interesting events of this kind took place in the Republic of Moldova. Thus, in February 2011, a mini-football tournament was organized, in which representatives of embassies and diplomatic missions accredited in the Republic of Moldova took part. Within the framework of this tournament, interesting aspects of the psychology of a diplomat playing football were revealed. During the matches, all Caller's advice - to be "polite and courteous" or J. Cambon - to be "careful and observant", or V. Petrovsky - to be "reasonable and prudent" were discarded and "forgotten". The media reported that, despite the status of the players, the passions were serious. In this situation, in order to avoid the brewing conflict, Ambassador of the Russian Federation Valery Kuzmin, as one of the organizers of the competition, had to intervene [15].

In the Republic of Moldova, football competitions are held not only between embassies and diplomatic missions, but also between the ministries of foreign affairs. At the end of August 2020, employees of the Foreign Ministries of Moldova and Turkey, led by their ministers, met at the new football field in Comrat [16]. An equally interesting approach to "football diplomacy" was taken by the Hungarian Ambassador to Moldova Sandor Szabo, a former professional footballer. On his initiative, an exhibition of photographs was opened in the National Museum of Fine Arts, dedicated to the 65th anniversary of the victory of the Hungarian national team over England with a score of 6: 3 . Before this meeting, the British had not lost a single national team at home for 90 years [17].

The universal history of sports reliably demonstrates that football is the strongest social attractor and a factor in the consolidation of public relations. In one of his works dedicated to Moldovan statehood, V. Beniuc emphasized in this context: "It is important to find a unifying factor ... In this regard, it is imperative to invest in the creation of a worthy football team, of a European level, which would be loved by all Moldovans, regardless of ethnic, religious or social affiliation. This should be a team-symbol, a team-pride, a teamdignity, a team that represents us in the world" $[24$, p.36]. 
Undoubtedly, the Olympic Movement and football championships are the most effective instruments of foreign policy, public diplomacy and soft power of any country, including the Republic of Moldova. However, it should be noted that each sports federation is a kind of ambassador in its sport. The very fact of their participation in international championships is an opportunity to represent not only the level of skill of athletes, but also the qualifications of coaches, the effectiveness of the training system for representatives of high sport, the ability of the state to ensure the modern level of development of sports and, most importantly, it is the opportunity to represent the country, raise its prestige, increase its authority among other countries. However, in each state there is a certain sport that develops better than others for certain reasons, including the inclination of young people to engage in this particular sport, established traditions in this regard, the presence of continuity in its development, prestige, etc.

Dance sports, in our opinion, are closer to these causal characteristics, a kind of sport in Moldova. Besides the fact that they represent a beautiful and graceful sport close to some of the traits of the professional behaviour of a classical school diplomacy, they are also the most successful sport practiced in the Republic of Moldova.

Judging by the materials published in the media, this sport adequately represents Moldova on the world stage. The very headings of numerous articles speak eloquently about this: "Dance sports: A pair of Moldovan dancers set a World record"; "Moldovan dancers left 38 countries behind them (from 39 AD)"; "Moldovan dancers won gold at the World Championship"; "A pair of Moldovan dancers won a gold medal at a competition in Colombia"; "The dance club "Codreanca" won 21 medals at the international tournament in Ukraine", etc. [18]

This sport requires a well-oiled management and serious costs, especially for the organizers of various championships. The number of participants can be from several hundred to several thousand athletes. Thus, more than 400 pairs of dancers took part in the International Festival of Sports Dance "Chisinau International Open - 2014" [19]; in the International Tournament for Children and Youth, held in January 2014, about 1000 teams took part, which included more than 3500 people [20]. In this sense, sports dances undoubtedly represent serious image opportunities for Moldova and its representation in the international arena. The importance of the Moldovan sports dance school was indicated by the choice in 2013. President of the Dance Sports Federation of Moldova, Petru Gozun, Vice-President of the European Dance Sports Union [21].

Sport in general and high sport in particular is part of the socio-political and economic system of any society. Therefore, the categories "general" - sports in general and "particular" - sports of the highest achievements, do not just interact with each other. In this case, the "general" determines the functionality of the "private", in other words, systemic support for sports, the education of the young generation in sports, systemic investments in the development of the infrastructure of mass sports, are an indispensable condition for the development of high sports as a factor in the development of public diplomacy and the implementation of "soft power" as unconditional support in the implementation of the foreign policy of the Moldovan state. 
References:

1. Синчук Роман. Футбол сильнее апартеида: как сборная ЮАР довела до слез Манделу https://www.ua-football.com/foreign/africa/1586677244-futbol-silnee-aparteida-kaksbornaya-yuar-dovela-do-slez-mandelu.html (дата посещения: 14.10.2020)
2. Никулашкина
Мария.
Мандела
и спорт.
https://www.sport-

express.ru/chronicle/reviews/821091/ (дата посещения: 15.10.2020)

3. Ильгар Велизаде. Турция-Армения: футбол без границ https://ria.ru/20090907/184010628.html (дата посещения:15.10.2020)

4. Маргарита Кальц. Армения и Турция подписали договор о нормализации отношений https://www.dw.com/ru/a-4781020 (дата посещения: 16.10.2020)

5. Алиев и Пашинян в Душанбе договорились https://regnum.ru/news/polit/2491142.html (дата посещения: 17.10.2020)

6. Премьер Молдовы и глава Приднестровья вновь встретятся на футбольном матче. https://korrespondent.net/world/1121837-premer-moldovy-i-glava-pridnestrovya-vnov-vstretyatsyana-futbolnom-matche (дата посещения: 17.10.2020)

7. Молдавский премьер приедет в Тирасполь на матч Лиги Европы "Шериф" "Динамо" (Киев) https://point.md/ru/novosti/politika/moldavskij-premjer-priedet-v-tiraspolj-namatch-ligi-evropi-sherif---dinamo-kiev (дата посещения: 18.10.2020)

8. Филат и Смирнов договорились о восстановлении телефонной связи между Молдавией и ПМР https://regnum.ru/news/polit/1331331.html (дата посещения: 23.10.2020)

9. Смирнов не созрел для переговоров http://www.vedomosti.md/news/ Smirnov_Ne_Sozrel_Dlya_Peregovorov (дата посещения: 23.10.2020)

10. Аудронюс Ажубалис. «Футбольная дипломатия» и Приднестровье. https://www.golosameriki.com/a/obse-usa-prednestrovie-2011-02-09-115650684/202863.html (дата посещения: 24.10.2020)

11. В отношениях Молдовы и Приднестровья приемлема только «футбольная дипломатия»? https://www.kp.md/daily/25717/916406/ (дата посещения: 24.10.2020)

12. Президент Приднестровья и премьер Молдавии провели очередную встречу на футбольном матче в Тирасполе https://regnum.ru/news/polit/1423632.html (дата посещения: 25.10.2020)

13. "Футбольную дипломатию" сменила "футбольная война": приднестровский клуб оштрафован за "неуважение" к гимну Молдавии https://regnum.ru/news/polit/1667359.html (дата посещения: 25.10.2020)

14. Дипломаты сыграли в футбол: посольство Молдовы не осталось в долгу https://ru.sputnik.md/world_sports/20170924/14702367/diplomaty-sygrali-v-futbol-posolstvomoldovy-ne-stalo-isklyucheniem.html (дата посещения: 26.10.2020)

15. Турнир по мини-футболу среди сотрудников министерств http://www.boviline.md/news/news/22-11-2016/773/ (дата посещения: 26.10.2020)

16. Дипломаты Молдовы и Турции сыграли «товарищеский матч» в Комрате https://point.md/ru/novosti/politika/diplomaty-moldovy-i-turtsii-sygrali-tovarishcheskii-match-vkomrate (дата посещения: 27.10.2020)

17. Выставка, посвященная победе сборной Венгрии по футболу над командой Англии, открылась в Кишиневе. http://www.infotag.md/interview/269760/ (дата посещения: 28.10.2020);

18. Танцевальный клуб «Кодрянка» выиграл 21 медаль на международном турнире в Украине http://moldova.sports.md/sports_dancing/news/28-06-2013/24602/ tanceval_nyj_klub_kodr_anka_vyigral_21_medal_na_mezhdunarodnom_turnire_v_ukraine/ (дата посещения: 12.11.2020); Спортивные танцы: Пара молдавских танцоров установила Мировой 
рекорд

http://moldova.sports.md/sports_dancing/news/01-12-2019/154177/ sportivnyje tancy_para_moldavskih_tancorov_ustanovila_mirovoj_rekord/ (15.11.2020); Молдавские танцоры завоевали золото на Чемпионате мира по спортивным танцам https://actualitati.md/moldavskie-tancory-zavoevali-zoloto-na-chempionate-mira-po-sportivnymtancam (13.11.2020)

19. В Молдове пройдёт танцевальное событие мирового масштаба http://eurasianews.md/society/moldove-projdyot-tantsevalnoe-sobytie-mirovogo-masshtaba.htm (дата посещения: 16.11.2020)

20. Сборная Молдовы по современным танцам отправится в Хорватию на Кубок мира http://moldova.sports.md/sports_dancing/news/21-012014/48235/sbornaja_moldovy_po_sovremennym_tancam_otpravits_a_v_khorvatiju_na_kubok_mi ra/ (дата посещения: 16.11.2020)

21. Петру Гозун стал вице-президентом Европейского союза танцевального спорта http://moldova.sports.md/sports_dancing/news/15-112013/40857/petru_gozun_stal_vice_prezidentom jevropejskogo_sojuza_tanceval_nogo_sporta/ (дата посещения: 16.11.2020)

22. Молдова: статистика участия в https://olympteka.ru/olymp/country/profile/mda.html (дата посещения: 20.11.2020)
23. Поезд Кишинев-Одесса пустили через Приднестровье https://ukraine.segodnya.ua/ukraine/poezd-kishinev-odecca-puctili-cherez-pridnectrove216810.html (дата посещения: 21.11.2020)

24. Бенюк В. (2017). Историческая преемственность молдавской государственности: междисииплинарное исследование. B: "Statalitatea Moldovei: continuitatea istorică şi perspectiva dezvoltării", conferinţă ştiinţifică internaţională (2017; Chişinău). Statalitatea Moldovei: continuitatea istorică şi perspectiva dezvoltării": Materialele Conferinţei ştiinţifice internaţionale, 24-25 martie 2017. Chişinău: IRIM, (Tipogr. "Print-Caro"). 851 p. 